\title{
Overview of Fuels used for Marine Diesel Engines
}

\author{
Van Vang Le
}

\begin{abstract}
In the future, when traditional fuels are exhausted, biofuels are the alternative candidate. The more developed the world, the greater the demand for fuel, while the natural resources are not unlimited. Therefore, the search for a new fuel source is more plentiful, more sustainable, less polluting, greenhouse effect and environmentally friendly as well as an opportunity to manage natural resources. In the maritime industry, most of the ships currently are using diesel engines as a propulsion device for propeller spinning, hybrid generators or other equipment. The main solution is to accelerate the research and deployment of applications into practical exploitation and encourage the use of biofuels. To enhance the building of material foundations, the training of human resources, the improvement of the system of policies, legal documents and the enhancement of international cooperation in biofuels development, raising public awareness. on the development of biofuels.
\end{abstract}

Index Terms-Diesel Engines; Maritime; Fuel; Alternative Fuel.

\section{INTRODUCTION}

Marine diesel engines are internal combustion engines, the combustion of diesel fuel occurs in the combustion chamber when the piston approaches the upper dead zone in the compression phase, fuel is injected, blended, evaporated and burnt under the effect of temperature and high pressure of compressed air [1],[2]. Diesel engines were invented by a German engineer, Rudolf Diesel in 1892. The diesel engine cycle was also called the diesel cycle.

In the world with the great development of the industry, manufacturing for a very long time, the use of diesel engines in the agricultural industry, industry, transportation is very extensive, with the capacity and large scale [3]. Not only have industrialized countries applied early, but they have also improved to meet the growing demand in the world today [4],[5]. From rudimentary engines, large, bulky components over time have become compact, shape, design, and modern in automation and control systems [6]. Because of the advantages of a diesel engine compared to a gasoline engine such as higher engine efficiency, cheaper fuel, use of fuel mixture and quality is not too rigorous diesel engines. It is widely used in many branches and fields.

In the industrialization and modernization of the day, the use of small diesel engines has played an important role in contributing to the development of the national economy in such areas as manufacturing, agriculture, transportation, road, and water transport [7]. For small-sized diesel engines, to operate efficiently and meet the requirements in the fields of exploitation and production, besides the improvement of

Published on October 17, 2018.

Van Vang Le is with Ho Chi Minh city University of Transport, Ho Chi Minh city, Vietnam. engine structure to improve capacity, economic indicators [8]. There are other research projects such as the production of new fuel, biofuel replacing a traditional and friendly fuel, without environmental pollution, greenhouse effect [9],[10]. These studies have been studied and applied by many countries, organizations, and scientists around the world with the aim of being environmentally friendly and reducing harmful emissions to the environment [11].

In Vietnam, diesel engines have been used extensively in agriculture, industry, transportation, and waterways for a long time [12]. Vietnam is a war-torn country, and we are now a developing country with a backward, agricultural, industrial, transportation backwardness. Development lags far behind other countries in the region and in the world in all areas so that the application of technology and industrial products in the world is always in the water [13]. The State attaches great importance to investment, especially for investors who create superior products [14]. The application of modern machines to production is prioritized for development. In that small diesel engine is focused development and practical application in the manufacturing industry, as for some cars of Hyundai, Mercedes etc. According to the general development trend above In the world as well as in Vietnam, in the next few years, the use of new generation of small-sized diesel engines is strongly developed thanks to the advantages such as fuel economy, smooth operation, and no pollution.

In the field of agriculture, forestry, and fisheries, small diesel engines are used as a motive force for soil preparation, water pumping, animal feed suppression, milling machines etc [15]. Small diesel engines are also made into tractor mixes, shore-based generators for companies, plant enterprises, etc. Most small diesel engines operate at stable speeds and are close to the design revolutions, which are suitable for industries and fields. Production and exploitation on shore [16]. The design of the engine is simple, easy to use, repairs, extracts and maintains maintenance. In the field of marine diesel engines are widely used on all surface ships and even submarines in the field of the military. The advantages of diesel engines compared to petrol engines are that the shipbuilders, diesel generators, investors and operators have put their trust in diesel engines [17]. Diesel engines are installed under the ship as a driving force to push ships, hybrid generators, hybrid pumps ... Depending on the purpose of use, the diesel engine installed under the ship has many different types of power such as dynamics. High-speed slow-motion engines, high-speed engines, medium-speed engines, and smallcapacity engines [18]. Along with that is the fuel used for engines as well as light fuel (DO), heavy fuel (FO) and fuels blend between fuel (DO) with vegetable oils and dynamite. object.

Today, all advances in science and technology, 
manufacturing of diesel engines are eager to create new generations of engines that meet the needs and purposes of people, meeting the conditions of use. and especially to meet the problem of emissions do not pollute the environment, the greenhouse effect. In particular, the use of new fuels, traditional biofuels replacing traditional fuels, is an urgent need. The introduction of new fuels and biofuels into diesel engines is a small diesel engine.

\section{CHARACTERISTICS OF SMALL MARINE DIESEL ENGINES}

Diesel-powered marine engines usually function as powertrain main propulsion or alternator motors, or hybrid alternators. In addition to the general structural features, marine diesel engines have a number of distinct characteristics compared to fixed-mounted diesel engines or vehicles fitted on road transport vehicles. This is due to the special requirements for features, working conditions, operating and installation conditions as well as current regulations and regulations as required by the IMO. In practice, the classification of marine diesel engines is based on rotation and capacity into three categories (Table I).

TABLE I: CLASSIFICATION OF MARINE DIESEL ENGINES

\begin{tabular}{lccc}
\hline \multicolumn{4}{c}{ TABLE I: CLASSIFICATION OF MARINE DIESEL ENGINES } \\
$\begin{array}{l}\text { Technical } \\
\text { parameters }\end{array}$ & $\begin{array}{c}\text { High-speed } 4 \\
\text { strokes }\end{array}$ & $\begin{array}{c}\text { Engine types } \\
\text { Medium-speed } \\
4 \text { strokes }\end{array}$ & $\begin{array}{c}\text { Low-speed } 2 \\
\text { strokes }\end{array}$ \\
\hline $\begin{array}{l}\text { Piston speed } \\
{[\mathrm{m} / \mathrm{s}]}\end{array}$ & $>8,5$ & $6,5 \div 8,5$ & $\leq 6,5$ \\
$\begin{array}{l}\text { Crankshaft } \\
\text { revolution } \\
{[\mathrm{v} / \mathrm{p}]}\end{array}$ & $960 \div 3000$ & $400 \div 1000$ & $50 \div 250$ \\
Power [kW] & to 5000 & $500 \div 30.000$ & $1.500 \div$ \\
\hline \hline
\end{tabular}

Diesel engines for main propulsion engines, hybrid generators, hybrid auxiliary equipment, capable of stable operation, reliable for a long time, continuous, in the environment of frequent changes in physical conditions (temperature, humidity, etc.) and chemical (salinity in air) [17]. With the requirements of safety, reliability and economy as stated in the International Maritime Organization (IMO) Convention on Marine Life Safety SOLAS 74, Used on marine vessels, usually designed to work with a rotation of $50 \mathrm{v} / \mathrm{p}$ (two-stroke engine capacity) to $1500 \mathrm{v} / \mathrm{p}$ (four-cycle engine generators or hybrid propellers in small ships), in addition to the engines mounted on military ships, the rotation is up to $2500 \mathrm{v} / \mathrm{p}$, while the higher speed engines as classified in (Table I) can be fitted on small cruise ships for the purpose of tourism or in military vessels and other service vessels. In the design and manufacturing process, the working cycle of the engine determines the time it takes to fuel the engine and, accordingly, the appropriate fuel. To see the fuel consumption of the engine shown above (Table II), take the rotational value of some of the typical engines to calculate and show how long the fuel is fed to the engine depending on their working speed.

TABLE II: THE DEPENDENCE OF FUEL SUPPLY TIME ON THE ENGINE SPEED

\begin{tabular}{ccccc}
\hline \hline & \multicolumn{4}{c}{ Engine types } \\
Parameters & 3000 & 1500 & 600 & 94 \\
& $\mathrm{rpm}$ & $\mathrm{rpm}$ & $\mathrm{rpm}$ & $\mathrm{rpm}$ \\
\hline
\end{tabular}

\begin{tabular}{lcccc}
\hline $\begin{array}{l}\text { Fuel injection } / 30^{0} \\
\text { BTDC/[s] }\end{array}$ & 0,0016 & 0,0033 & 0,0083 & 0,044 \\
$\begin{array}{l}\text { Times of fuel injection per } \\
\text { a second }\end{array}$ & 25 & 12,5 & 5 & 1,566 \\
\hline \hline
\end{tabular}

From Table II, it can be clearly seen that:

- High-speed diesel engines (from 1500 to $3000 \mathrm{rpm}$ ), fuel injection times are very short and occur only within 0.0016 to $0.0033 \mathrm{~s}$. For this type of engine, the fuel used is MGO (marine gas oil) light diesel with high quality and relatively expensive price. HFO (heavy fuel oil) will adversely affect engine performance, as heavy HFO oil will require longer evaporation time to mix with the resulting air. complete combustion mixture.

- $\quad$ For medium and low speed diesel engines (from 600 to $94 \mathrm{rpm}$ ), the fuel delivery time will be longer than the high speed motor and occurs from 0.0083 to $0.044 \mathrm{~s}$. With this type of diesel engine, it is possible to use HFO with lower quality and price.

With specifications such as marine diesel engines are usually quite easy to use in the use of different fuels, from distillate fuel to HFO. In fact, in order to increase the economics of the operation of medium speed and low speed diesel engines on board, HFO fuel is used mainly. Low viscosity distillate fuels are often used in unstable operating modes, transition modes to ensure operating parameters of engines. All types of fuel have their own characteristics, which meet the requirements of the engine in terms of structure, operation and operation of engines such as: density, heat value, viscosity, freezing temperature, fire temperature, ash value, ash content, sulfur content, water content.

Therefore, the shipping vessels usually use two-speed motor $(50-210 \mathrm{rpm})$ as the main engine. At the same time, auxiliary engines use four-stroke diesel engines with or without turbochargers. Specialized vessels such as tugs, ferry boats, ocean-going vessels, high-speed and high-speed diesel engines (>1500 rpm) are widely used as main engines. Currently, nearly $100 \%$ of river ships and marinebased ships are equipped with diesel power stations. The number of seagoing vessels also accounts for $95-97 \%$ of the total installed diesel power equipment.

\section{FUEL FOR MARINE DIESEL ENGINES}

Generally, the fuel used for diesel engines will be determined by the specific technical characteristics of the engine as described in section II. The International Organization for Standardization (ISO) therefore sets standards for fuels suitable for diesel engines, including diesel engines. The mandatory standards for diesel engine fuels are based on the properties of fuels such as: density, calorific value, cyanide, sulfur content [17]. This also serves as a basis for assessing the suitability, reliability and safety of a fuel when used as a substitute for marine diesel.

According to US standards, diesel is divided into six different grades numbered from 1 to 6 depending on boiling point, chemical composition, purpose of use and viscosity (the higher the viscosity, the higher the index). The viscosity of diesel No. 6 is the highest and the number 1 is the lowest. 
Diesel grades numbered 1 to 3 are usually distilled diesel. Diesel No. 1 is kerosene, also called steam oil because it burns out completely when heated. Diesel No. 2 (also known as diesel oil) is a diesel fuel used primarily for road diesel and diesel engines with the characteristics shown in Table III. Diesel No. 6 is the rest of the crude oil after all the components such as gasoline, kerosene and fuel oil component 2 evaporate, so it's also called sludge or heavy oil. Diesel No. 4 is the blend of Diesel No. 2 and No. 6 Diesel. Diesel No. 5 is also a blend of the two, with a higher ratio of Diesel 6 in the mixture and up to $75 \%$ mass.

TABLE III: TECHNICAL PARAMETERS OF DIESEL NO. 2 (DO)

\begin{tabular}{lccc}
\hline \multicolumn{1}{c}{ Parameters } & Unit & Value & Standard \\
\hline Sulfur content & $\%$ mas & 0,36 & EETD 86 \\
Flash point & ${ }^{\circ} \mathrm{C}$ & 91 & EETD 84 \\
Density at $15^{\circ} \mathrm{C}$ & $\mathrm{Kg} / \mathrm{m}^{3}$ & 846,4 & EETD 84 \\
Pour point & ${ }^{\circ} \mathrm{C}$ & -27 & Mackay $82 \mathrm{~b}$ \\
Kinematic viscosity at $20^{\circ} \mathrm{C}$ & $\mathrm{cSt}$ & 4 & Mackay $82 \mathrm{~b}$ \\
Dilution at $20^{\circ} \mathrm{C}$ & $\mathrm{Kg} / \mathrm{m}^{3}$ & 3 & Mackay $82 \mathrm{~b}$ \\
\hline \hline
\end{tabular}

Although marine diesel engines work in a variety of fuels, when the fuel is working on a diesel engine, it will need to meet rigorous requirements such as fire and explosion requirements. Ensure safety on board.

- The ignition point of the fuel used for the main diesel engine on the ship shall not be less than $60^{\circ} \mathrm{C}$.

- Fuel temperature must be lower than flash point in $10^{\circ} \mathrm{C}$.

- Fuel needs high stability, ensuring that the heavy components in the fuel are not separated and settled to the bottom of the tank. As long as the ships operate on the sea, they must store a large amount of fuel (thousands of tons of oil) and work under constant weather and climate conditions

- Because marine diesel engines are usually low-speed and mid-speed engines, the ability to use low-quality fuels, mechanical components, sulfur, etc. is relatively high. This is a major source of environmental pollution of water transport vehicles.

Another problem with on-board fuel relates to the mode of operation of marine diesel engines that is negatively impacting the environment. In the exhaust gas of diesel engines are often many different environmental toxins, including $\mathrm{NOx}, \mathrm{COx}$ and $\mathrm{SO} 2$ constitute the major constituents with content of over $80 \%$ by mass. This amount of toxic waste is increased when the engine is operating in unstable conditions. Thus, with the large number of means of water transport, it is possible to see that the source of pollutant emissions from ships contributes a considerable part of the pollution of the whole world.

In recent years, the International Maritime Organization (IMO) has been trying to put in place many regulations on energy efficiency on board, thus controlling the amount of greenhouse gases generated, Technical standards and exploitation as follows:

- $\quad$ Energy Efficiency Design Index (EEDI)

- $\quad$ Energy Efficiency Operation Index (EEOI)

- Ship Energy Efficiency Management Parameter (SEEMP)
The Energy Efficiency Design Index (EEDI) can be considered as one of the technical standards to reduce $\mathrm{CO} 2$ emissions from ships. IMO's Marine Environmental Protection Agency (MEPC) has been continuously improving this set of rules to apply to fleets since 1997. In July 2011, mandatory regulations for EEDI, SEEMP was adopted and the SEEMP was formally incorporated into Annex VI of the International Convention for the Prevention of Pollution from Ship (MARPOL73 / 78) applicable to all existing and newly built vessels 400 or more. Subsequently, the revised Annex VI of MARPOL 73/78 entered into force on January 1, 2013 with the addition of a Chapter 4 "Ship Energy Efficiency Regulation". In fact, shipping is considered to be the least expensive one tonne - nautical mileage transport and is more advantageous than other modes of transport due to its ability to handle large volumes of cargo, Range is far away but only with minimal fuel costs. However, the exploitation of ships is encountering the following problems:

- Big fuel costs, fuel efficiency is not high.

- Technical management and ship exploitation is loose, almost passive.

TABLE IV: STANDARD OF NOX EMISSIONS

\begin{tabular}{lccc}
\hline \hline \multicolumn{1}{c}{ Standard } & \multicolumn{3}{c}{ Total mass of NOx [g/kWh] } \\
& $\begin{array}{c}\mathrm{n}<130 \\
\mathrm{rpm}\end{array}$ & $\begin{array}{c}130 \leq \mathrm{n} \leq \\
2000 \mathrm{rpm}\end{array}$ & $\begin{array}{c}\mathrm{n} \geq 2000 \\
\mathrm{rpm}\end{array}$ \\
\hline $\begin{array}{l}\text { For marine engines before } \\
1 / 1 / 2000\end{array}$ & 17,0 & $45,0 \times \mathrm{x} \mathrm{n}^{(-0,2)}$ & 9,8 \\
$\begin{array}{l}\text { For marine engines after } \\
1 / 1 / 2000 \text { and before 1/1/2011 }\end{array}$ & 17,0 & $45,0 \times \mathrm{x} \mathrm{n}^{(-0,2)}$ & 9,8 \\
$\begin{array}{l}\text { For marine engines after } \\
1 / 1 / 2011\end{array}$ & 14,4 & $44,0 \times \mathrm{x} \mathrm{n}^{(-0,2)}$ & 7,7 \\
$\begin{array}{l}\text { For marine engines after } \\
1 / 1 / 2016\end{array}$ & 3,4 & $9,0 \times \mathrm{n}^{(-0,2)}$ & 2,0 \\
\hline \hline
\end{tabular}

The issues mentioned negatively affect the efficiency of vessel operation especially when fuel prices and associated transport costs continue to increase while freight rates decrease. Therefore, efficient use and management of fuel is of particular interest [19]. In Vietnam, the National Assembly approved the law on energy efficiency and conservation on June 17, 2010, in which Chapter IV specifically regulates the transportation sector. Accordingly, on October 2, 2012, the Government issued Decision No. 1427 / QD-TTg approving the national target program on "Energy Efficiency and Conservation in 2012-2015", with a Among the outstanding objectives is "Development of transportation system to meet the demand of transport with higher quality, fuel saving and limited pollution. Promote the application of new technologies, using renewable energy to replace traditional fuels in transportation. " To realize this issue, the Government focuses on "Applying new technologies, renewable energy in transportation" with the following main contents:

- Applying new technical innovations and technologies in transportation to save energy, reduce pollutant emissions.

- Deploying renewable energy and alternative fuels (CNG, LPG, LNG, biofuel, electric energy and other potential energy) for means and transport equipment. to improve the efficiency of energy use.

In 2009, the IMO's Greenhouse Gas Research Council 
aggregated seven types of fuels that could be used in the maritime sector: distillate oil, heavy oil, LNG, PLG, biodiesel fuel. biotech and original vegetable oils), synthetic diesel (FTD) and other recyclable fuels [20],[21]. However, considering the extent of the environmental impact, including the emission of emissions from use and the emission of emissions from the production of fuels, there are two more highly rated fuels, LNG and diesel. biological.

On August 31, 1937, at the University of Brussels, G. Chavanne soon received a patent (Belgian patent -422,877) for the first time that vegetable oil reacted with ethanol, methanol and That's biodiesel now.

US: It is the country that uses biodiesel in the most popular shipping sector and has set many regulations on the use of biodiesel since 1992 when applied on ships. Many US organizations have successfully implemented a pilot program for the application of biodiesel blends with B1 to B100 diesel, especially on reducing emissions from ships and protecting the marine environment such as The experiment was conducted by the Washington State Sea Ferry Association (WSF) and the Royal Caribbean Railway Corporation (RCCL) on both the main diesel engine and the gas turbine. The WSF is the leading research organization for biodiesel applications in the ferry system since 2003 and is currently using the B20 primarily on association ferries. In addition, biodiesel is widely used in US naval vessels as well as US Coast Guard ships (USCG) as an environmentally friendly fuel that meets the stringent requirements of the US Navy. organizations and associations for environmental protection in the country.

A survey of the use of biodiesel on 100 cruise ships operating in the San Francisco Bay Area from 1994 to 1997 showed a positive response from boat owners for this fuel. Most of the ships are over 20 years of age and use diesel engines from Mercedes, Yanma, Isuzu, Volvo ... about $75 \%$ of ships use biodiesel blends at rates of over $25 \%$ and nearly 1/Number of boats using B 100 .

In Denmark, in 2007, the Scandlines ferry called "Fanffergen" tested the use of the B100 biodiesel engine on a 600 watt Caterpilar 3412 engine. The result was positive and did not need to be. Adjust the system before use. This result has a strong impact on engine manufacturers as well as ship owners towards the increased use of biodiesel on ships.

Wartsila (Finland), one of the world's leading marine engine manufacturers, has begun looking for alternative energy sources since the 1980 s, especially those that use biofuels. Learn on the engines manufactured by the manufacturer. In 1995 the company succeeded in testing diesel oil as a fuel for diesel engines and by 2003 had installed in the Federal Republic of Germany the first energy system powered by vegetable oils used for commercial purposes. Commerce. Most recently, STX Finland has signed a commercial contract with Wartsila with three $4 \mathrm{~L}$ 6L20 bio-fuel (Liquid Bio Fuel) engines with a capacity of $1,026 \mathrm{~kW}$, a revolving $750 \mathrm{v} / \mathrm{p}$ engine. electric propulsion for 2 propeller ships Aura II capacity of 4,700 DWT launched in 2012.

Wartsila's main technology is to design, improve and manufacture new fuel systems, especially high-pressure pumps. According to the company's experiments, the phenomenon of air bubbles in the high-pressure fuel feed system, which leads to corrosion and damage to the surface of the components, is of particular concern when using biofuels. Air bubbles can appear in the oil reservoir chamber before entering the high pressure pump or in front of the injector, causing the engine to operate unstable at a load. With its biofuel engine, the company designed the optimized low pressure fuel cell in the high pressure pump. It also pays special attention to the mobility of fuel on its way through the low-temperature bio-fuel. Therefore, maintaining fuel temperature in the range of $10-150 \mathrm{C}$ above the freezing temperature is extremely necessary, in addition to paying attention to the slope allows easy mobility.

MAN B \& W (Germany) started research on the use of biodiesel fuel after 1994. Although it did not focus on shipto-ship studies, the company also achieved many results when tested. Test the compatibility of many biofuels with their engines to create the most suitable fuel. In 2001, the company tested the deployment of a bio-diesel powered system powered by a $750 \mathrm{~kW}$ engine and then tested lowand mid-speed engines. MAN B\&W's bio-fuel research effort was launched in 2007, when it was commissioned in Mouscron, Belgium, a hybrid power generation system equipped with a four-stroke engine. The 18-cylinder $18 \mathrm{~V} 48$ / 60 has the largest capacity (17.7 MW) of biofuel. The company also provides a large number of diesel engines using biofuels for other power plants. The company also confirmed the possibility of applying biofuels on ferry boats, but the biggest obstacle is the high cost of fuel compared to traditional diesel fuel. Combined with studies and evaluations by other diesel engine manufacturers such as Caterpilla or Rolls Royce / Bergen Diesel, it is concluded that biofuels can meet Good response to use on board. Actually biodiesel has many physical and chemical characteristics that are similar to traditional diesel, but in between them there are still differences so apart from having to improve the main details as mentioned, Other components of the fuel system such as: storage tank, separator, direct deposit, mixer. Studies have shown that the use of B100 biodiesel fuel is possible, however, with many negative effects on engine specifications, engine economy, wear and tear of engine parts, and damage. the sealing details, ... and need to study further. As for the mixing of biodiesel and diesel for different ratios ranging from $5 \%$ to $20 \%$ biodiesel in the mixture, the above factors are not nearly as great. However, the mixture between biodiesel and diesel is not very stable, so it is classified and split very quickly, resulting in poor mixing quality, affecting the exploitation of the engine. Another important limiting factor of this research is the high cost of biodiesel due to the costs of extracting biodiesel from the original vegetable oil or animal fats through esterification to reduce the Fat contained in the composition.

\section{CONCLUSION}

The use of different fuels leads to different exploitation features and problems that arise if not explored beforehand. The operating mode of the ship's engines is constantly changing according to the external environment (wave, wind, temperature, humidity, etc.) and operating 
requirements. Therefore, Minimize the impact on fishing characteristics. In addition, the factors of storage conditions, preservation of biofuels on board also play a very important role in different environmental conditions. Therefore, the domestic research on the use of biofuels on the ship has not been focused development. Engineers have designed and built new generations of engines to directly use biodiesel or vegetable oils. This solution is mainly for the long-term purpose, the current cost of engines and fuel prices are high, so not meet the current demand.

Unchange the engine structure, only heat the biodiesel to the temperature, where the viscosity is equivalent to diesel and directly to the diesel engine. This method is simple, easy to apply to the engine installed on the shore, but the technical specifications, the engine does not guarantee, with a great impact on the process of corrosion, scale At the breakdown, sealed gaskets reduce engine life.

Blends biodiesel with diesel at a rate of $50 \%$ used for engines installed on cruise ships, short journey times. The blended fuel is on the shore and supplied to the consumer as an available fuel, but the mixture is not highly stable or classified, especially under thermal conditions. low environmental conditions. This is one of the great obstacles to using biofuels as a substitute for diesel engines on ships.

\section{REFERENCES}

[1] Y.-C. Lin, K.-H. Hsu, and C.-B. Chen, "Experimental investigation of the performance and emissions of a heavy-duty diesel engine fueled with waste cooking oil biodiesel/ultra-low sulfur diesel blends," Energy, vol. 36, no. 1, pp. 241-248, 2011.

[2] T. A. Hoang, N. X. Chu, and T. Van Tran, "The Environmental Pollution In Vietnam: Source, Impact And Remedies," Int. J. Sci. Technol. Res., vol. 6, no. 2, pp. 249-253, 2017.

[3] A. T. Hoang, "Waste heat recovery from diesel engines based on Organic Rankine Cycle," Appl. Energy, vol. 231, pp. 138-166, 2018.

[4] S. Ushakov, H. Valland, J. B. Nielsen, and E. Hennie, "Effects of high sulphur content in marine fuels on particulate matter emission characteristics," J. Mar. Eng. Technol., vol. 12, no. 3, pp. 30-39, 2013.

[5] A. T. Hoang, Q. V. Tran, and X. D. Pham, "Performance and Emission Characteristics of Popular 4-Stroke Motorcycle Engine in Vietnam Fuelled with Biogasoline Compared with Fossil Gasoline,' Int. J. Mech. Mechatronics Eng., vol. 18, no. 2, pp. 97-103, 2018.

[6] A. T. Hoang and V. T. Nguyen, "Emission Characteristics of a Diesel Engine Fuelled with Preheated Vegetable Oil and Biodiesel," Philipp. J. Sci., vol. 146, no. 4, pp. 475-482, 2017.

[7] V. D. Tran, A. T. Le, V. H. Dong, and A. T. Hoang, "Methods of operating the marine engines by ultra-low sulfur fuel to aiming to satisfy MARPOLAnnex VI,” Adv. Nat. Appl. Sci., vol. 11, no. 12, pp. 34-40, 2017.

[8] T. A. Hoang and V. Van Le, "The Performance of A Diesel Engine Fueled With Diesel Oil, Biodiesel and Preheated Coconut Oil," Int. J. Renew. Energy Dev., vol. 6, no. 1, pp. 1-7, 2017.

[9] A. T. Hoang and V. V. Pham, "A study of emission characteristic, deposits, and lubrication oil degradation of a diesel engine running on preheated vegetable oil and diesel oil," Energy Sources, Part A Recover. Util. Environ. Eff., 2018.

[10] A. T. Hoang, "A report of the oil spill recovery and treatment technologies to reduce the marine environment pollution," Int. J. $e$ Navigation Marit. Econ., vol. 9, pp. 35-49, 2018.

[11] A. T. Hoang and V. V. Pham, "Impact of Jatropha Oil on Engine Performance, Emission Characteristics, Deposit Formation, and Lubricating Oil Degradation," Combust. Sci. Technol., 2018. https://doi.org/10.1080/00102202.2018.1504292

[12] A. T. Hoang, "A Design and Fabrication of Heat Exchanger for Recovering Exhaust Gas Energy from Small Diesel Engine Fueled with Preheated Bio-oils," Int. J. Appl. Eng. Res., vol. 13, no. 7, pp. 5538-5545, 2018

[13] A. T. Hoang, C. N. Luong, and A. T. Le, "Properties and Spray Characteristics of Heated Pure Coconut Oil Aiming a Direct Use in Conventional Diesel Engines," in The 5th TSME International Conference on Mechanical Engineering, 2014.

[14] B.-H. Lin, B.-X. Shen, and J.-G. Zhao, "A study on the prediction model for the lubricity of hydrogenated ultra-low sulfur diesel fuel," Energy Sources, Part A Recover. Util. Environ. Eff., vol. 33, no. 3, pp. 254-264, 2010.

[15] A. T. Hoang and A. T. Le, "A review on deposit formation in the injector of diesel engines running on biodiesel," Energy Sources, Part A Recover. Util. Environ. Eff., 2018. https://doi.org/10.1080/15567036.2018.1520342

[16] A. T. Hoang, "The Performance of Diesel Engine Fueled Diesel Oil in Comparison with Heated Pure Vegetable Oils Available in Vietnam,' J. Sustain. Dev., vol. 10, no. 2, pp. 93-103, 2017.

[17] V. V. Le, D. C. Nguyen, and A. T. Hoang, "The potential of using the renewable energy aiming at environmental protection," Int. J. Latest Eng. Res. Appl., vol. 2, no. 7, pp. 54-60, 2017.

[18] Anh Tuan Hoang and V. V. Pham, "A study of emission characteristic, deposits, and lubrication oil degradation of a diesel engine running on preheated vegetable oil and diesel oil," Energy Sources, Part A Recover. Util. Environ. Eff., 2018. https://doi.org/10.1080/15567036.2018.1520344

[19] A. T. Hoang and D. N. Cao, "Some methods of reducing NOx components in exhaust gas," Int. J. Eng. Res. Manag. Stud., vol. 4, no. 5, pp. 11-18, 2017.

[20] A. T. Hoang, "Prediction of the density and viscosity of biodiesel and the influence of biodiesel properties on a diesel engine fuel supply system," J. Mar. Eng. Technol., 2018. https://doi.org/10.1080/20464177.2018.1532734.

[21] A.T. Hoang, M.M. Noor, and X.D. Pham, "Comparative Analysis on Performance and Emission Characteristic of Diesel Engine Fueled with Heated Coconut Oil and Diesel Fuel," Int. J. Automot. Mech. Eng., vol. 15, no. 1, pp. 5110-5125, 2018. 